\title{
Copepod grazing and its potential impact on the phytoplankton development in the Barents Sea
}

\author{
ULF BÅMSTEDT, HANS CHRISTIAN EILERTSEN, KURT S. TANDE, DAG SLAGSTAD and HEIN RUNE \\ SKJOLDAL.
}

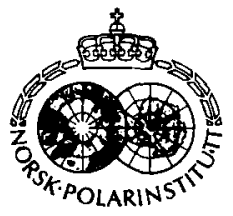

\author{
Båmstedt, U., Eilertsen, H. Chr., Tande, K. S., Slagstad, D. \& Skjoldal, H. R. 1992: Pp. 339-353 in \\ Sakshaug. E., Hopkins, C. C. E. \& Øritsland. N. A. (eds.): Proceedings of the Pro Marc Symposium on \\ Polar Marine Ecology. Trondheim, 12-16 May 1990. Polar Research 1012).
}

Compiled data from published and unpublished sources on copepod grazing of the large-sized copepods in the Barents Sea give wide ranges in grazing rates. Approximate average values indicate daily rations of 7-18\% for copepodite stages V and VI and considerably higher values for the earliest copepodite stages. It is demonstrated that individual variability in gut fullness of copepods from a given locality is typically very high and not closely related to variable food abundance or depth of occurrence. There is no die! feeding rhythm during the summer. and even when relating copepod grazing to a number of biotic and abiotic factors through stepwise linear regression analysis, much of the variability remains unexplained. It is suggested that feeding behaviour, food quality and feeding history of the copepods all play important roles as factors which regulate copepod grazing. Model simulations on the phytoplankton succession, using literature data on laboratory-determined growth characteristics for solitary cells and colonies of the prymnesiophyte Phaeocystis pouchetii and large diatoms, indicate that the extent of the mixed layer and selective grazing by zooplankton are important factors that may explain the occurrence of dense blooms of $\boldsymbol{P}$. pouchetii colonies, frequently observed during the spring.

$U$. Bämstedt, Department of Füsheries and Marine Biology, High-Technology Centre N-5020 Bergen, Norway; H.Chr. Eilertsen and K.S. Tande, Norwegian College of Fisheries, University of Tromsø, P.O. Box 3083 Guleng, N-900I Troms, Norway: D. Slagstad, SINTEF Automatic Control, N-7034 TrondheimNTH, Norway; H.R. Skjoldal, Institute of Marine Research, P.O. Box 1870 Nordnes, N-5024 Bergen, Norway (revised August 1991).

\section{Introduction}

The Barents Sea is a very important area economically for commercial fisheries; it is therefore of utmost interest to study the biological production in this area. Since the main pelagic fish stocks, capelin (Mallotus villosus) and herring (Clupea harengus), feed on zooplankton, there is a direct relation between production-related studies on zooplankton and the commercial fishery here. The limit for zooplankton production is primarily set by the amount of food consumed, and secondarily by the assimilation efficiency and the metabolic costs associated with life. Quantitative information on feeding by zooplankton may therefore be considered a tool which can be used to estimate zooplankton production, thereby providing important information for an estimation of the carrying capacity for planktivorous fish stocks. Zooplankton is also considered a major regulating factor for lower trophic levels. Zooplankton grazing may influence the development and succession in the phytoplankton community directly by (1) depressing the total stock and (2) depressing part of the stock by selective grazing. Indirectly it may influence the phytoplankton by (3) reducing the grazing pressure from microzooplankton by predation and (4) stimulating algal growth by regenerating plant nutrients. Estimates of the total impact of copepod grazing in the Barents Sea are restricted to point (1) above. These studies suggest that the impact is small in the spring (5-20\% of the primary production, Eilertsen et al. 1989a) but considerably larger during summer $(65-90 \%$ of the primary production, Eilertsen et al. $1989 \mathrm{~b} ; 10$ $400 \%$, Hansen et al. 1990a). In view of the fairly extensive new literature on feeding behaviour and food selectivity in copepods (e.g. Huntley 1988; Jonsson \& Tiselius 1990), points (2) and (3) are certainly also important. For example, one of the dominant algal species in the Barents Sea, the prymnesiophyte Phaeocystis pouchetii, may cause a reduction or even inhibition of the feeding in copepods (Dagg et al. 1982; Schnack et al. 1985, Verity \& Smayda 1989). Till now, this effect has not been demonstrated in field studies from the Barents Sea (Eilertsen et al. 1989b) or in labora- 
Table 1. Calculated individual carbon content $(\mu \mathrm{g})$ of the copepodite stages of large-sized copepods from the Barents Sca. Reference sources: (1) Protein content from the Barents Sea in May-June 1987 and conversion factors. Båmstedt 1986; (2) Slagstad \& Tande 1990; (3) Eilertsen et al. 1989b. Conover \& Corner 1968; (4) Dry weight from the Barents Sea in August 1988 and conversion factor, Båmstedt 1986. Stage IV copepodites represent adult females.

\begin{tabular}{lccccccc}
\hline Species/Stage & c-I & c-Il & c-Ill & c-IV & c-V & c-VI & Ref. \\
\hline Calanus finmarchicus & 3 & 8 & 23 & 64 & 193 & 231 & $(1)$ \\
Calanus glacialis & 4 & 8 & 25 & 100 & 264 & 576 & $(2)$ \\
Calanus hyperboreus & 7 & 16 & 77 & 230 & 743 & 1399 & $(3)$ \\
Metridia longa & - & - & - & - & - & 193 & $(4)$ \\
\hline
\end{tabular}

tory studies using the common copepod species in the Barents Sea (Tande \& Båmstedt 1987; Huntley et al. 1987; Hansen et al. 1990b). However, Estep et al. (1990) used an incubation technique and image analysis in a field study and found evidences for a variable feeding behaviour of Calanus finmarchicus and $C$. hyperboreus, related to the physiological condition of $P$. pouchetii. In this paper we give a brief review of quantitative data on copepod grazing from the Barents Sea and formulate a simple mathematical model that simulates the effect of copepod grazing on the phytoplankton succession during the first part of the production season.

\section{Material and methods}

\section{Copepod grazing rates}

The original papers should be consulted for a description of the material and methods used for the published data. The unpublished data from 1983 were based on in situ incubations and subsequent analysis with an Elzone ${ }^{\mathrm{TM}}$ particle counter (Båmstedt et al. 1985). Unpublished results from 1984 and 1987 were produced as described by Tande \& Båmstedt (1985), except that single copepods were analysed in the material from 1984. In 1987 , zooplankton was sampled by a slow, vertical haul, using a 1-m diameter WP-2 net with $300 \mu \mathrm{m}$ mesh and equipped with a nonfiltering cod-end, $15 \mathrm{l}$ volume. Healthy animals were sorted out and kept in $100 \mathrm{ml}$ of filtered seawater for up to $30 \mathrm{~min}$ prior to incubation. Ambient seawater samples from defined depths with the natural assemblage of particles were prepared in advance by mixing $3.7 \times 10^{3} \mathrm{~Bq}$ $(100 \mu \mathrm{Ci})$ of $\mathrm{NaH}^{14} \mathrm{CO}_{3}$ to $4 \mathrm{l}$ water in polycarbonate bottles and incubating them in natural light for 24 hours. The zooplankton samples $(100 \mathrm{ml})$ were mixed with $400 \mathrm{ml}$ radio labelled experimental water, using tissue-culture bottles of $500 \mathrm{ml}$ capacity, and incubated for $0.7-1.0 \mathrm{~h}$ at ambient temperature and dim light exposure. Incubation was finished by sieving off the copepods, anesthetising them with MS 222 (ethyl maminobenzoate), rinsing them individually and putting them into a scintillation vial with $0.5 \mathrm{ml}$ tissue solubiliser. Standard procedures were used in the subsequent preparation and scintillation counting of the, samples. Grazing rate, in terms of consumed food carbon, was calculated from the ambient concentration of particulate carbon and estimated clearance rate, as given below:

$\mu \mathrm{gC}$ intake $\mathrm{h}^{-1}=\mu \mathrm{g} \mathrm{C} \mathrm{\textrm {ml } ^ { - 1 }}$

$$
\times \frac{\mathrm{DPM}_{\text {copepod }} \times 2}{\left(\mathrm{DPM}_{\text {statt }}+\mathrm{DPM}_{\text {stop }}\right) \mathrm{ml}^{-1} \times \mathrm{h}_{\text {incubation }}}
$$

Individual content of body carbon for each species/stage (Table 1) was used in the calculation of daily rations ( food carbon intake as percentage of body carbon).

\section{Phytoplankton growth}

Laboratory-derived data on the growth characteristics of large diatoms and solitary cells and colonies of Phaeocystis pouchetii at $0^{\circ} \mathrm{C}$ (Verity et al. 1991 this volume) were used in the model formulation. These parameter values are summarised below and explained under Model formulation.

\begin{tabular}{|c|c|c|c|c|}
\hline Parameter & Diatoms & $\begin{array}{l}\text { Phoeocystis } \\
\text { solitary cells }\end{array}$ & $\begin{array}{l}\text { Phaeocystis } \\
\text { Colonies }\end{array}$ & Units \\
\hline$\mu$ & 0.33 & 0.3 & 0.22 & $d^{-1}$ \\
\hline$\alpha^{\beta}$ & 0.018 & 0.037 & 0.030 & $\mathrm{mg} \mathrm{C}(\mathrm{mg} \mathrm{Chl} a)^{-1}\left(\mu \mathrm{mol} \mathrm{m} \mathrm{m}^{-2} \mathrm{~s}^{-1}\right)^{-1} \mathrm{~h}^{-1}$ \\
\hline$\alpha^{c}$ & 0.0007 & 0.0005 & 0.0003 & $\mathbf{h}^{-1}\left(\mu \mathrm{mol} \mathrm{m}{ }^{-2} \mathrm{~s}^{-1}\right)^{-1}$ \\
\hline $\mathrm{Ch} a / \mathrm{C}$ & 0.04 & 0.0125 & 0.011 & \\
\hline
\end{tabular}




\section{Model formulation}

A mathematical model has been designed to assess the effect of grazing on the development of the primary production during the spring. The model contains a two-compartment model for phytoplankton and a population of single species of copepods (Calanus finmarchicus). The biological sub-models are driven by a 1-dimensional (1-D) model of the vertical water column.

Phytoplankton growth and distribution is described by a 1-D model of a vertical water column

$\frac{\partial P}{\partial t}+w \frac{\partial P}{\partial z}-\frac{\partial}{\partial z}\left(K_{z} \frac{\partial P}{\partial z}\right)=f_{\text {biol }}$

where $\mathrm{P}(\mathrm{t}, \mathrm{z})$ is the concentration of diatoms or Phaeocystis pouchetii, $\mathrm{w}$ is vertical velocity (usually sinking velocity) and $K_{z}$ is the vertical eddy diffusion coefficient. $f_{\text {biol }}$ represents the growth and mortality of the phytoplankton as described by equation 3 :

$\mathrm{f}_{\text {biol }}=\mathrm{P}\left\{\left(\frac{\mathrm{Chl}}{\mathrm{C}}\right) \mathrm{f}^{\mathrm{P}}(\mathrm{I})-\mathrm{r}-\mathrm{G}^{\mathrm{Z}}\right\}$

where $\mathrm{f}^{\mathrm{P}}(\mathrm{I})$ is a function that describes the relationship between photosynthetic rate $[\mathrm{mg} \mathrm{C}$ $\mathrm{mg}(\mathrm{Chla})^{-1} \mathrm{~h}^{-1}$ ] and light intensity (I), $\mathrm{r}$ is the phytoplankton respiration rate and $G^{Z}$ is the zooplankton grazing rate. The phytoplankton respiration constant was set at $0.05 \mathrm{~d}^{-1}$ (Båmstedt \& Tande 1985; Sakshaug \& Slagstad 1991 this volume). Sedimentation loss was assumed significant only for diatoms and a coefficient of $0.02 \mathrm{~d}^{-1}$ has been applied. Assuming no photoinhibition, the $P$ vs. I relationship is described by:

$$
\mathrm{P}^{\mathrm{C}}=\mathrm{P}_{\mathrm{m}}^{\mathrm{C}}\left\{1-\exp \left(-\frac{\alpha^{\mathrm{C}}}{\mathrm{P}_{m}^{\mathrm{B}}}\right)\right\}
$$

where $\mathrm{P}_{\mathrm{m}}^{\mathrm{C}}$ is maximum carbon-normalised photosynthetic rate and $\alpha^{C}$ is the carbon-normalised initial slope of the curve (see Table above, Webb et al. 1974 and Sakshaug \& Slagstad 1991). The model simulates a spring situation, which means that there are no nutrient limitations.

During the spring there is a transition from solitary cells to colonies of $P$. pouchetii, which has a somewhat lower growth rate (see above). However, the colonies seem to be controlled differently, and a mass bloom of colonies is a common feature in the late spring. The trigger mechanism for the formation of colonies is unknown, but they usually begin to form simultaneously with the occurrence of diatoms. Results from P-I measurements performed in the field between 1984 and 1989 showed decreased growth rate (based on carbon) of solitary cells of $P$. pouchetii when the amount of diatoms increased (Eilertsen unpubl. data). In the model we have therefore assumed that the production of $P$. pouchetii colonies is triggered by an increase in the diatom concentration and a switching from solitary cells to colonies at a diatom concentration of $1 \mathrm{mg} \mathrm{Chl} a \mathrm{~m}^{-3}\left(25 \mathrm{mg} \mathrm{C} \mathrm{m}^{-3}\right)$.

Surface irradiance was calculated from the theoretical high of the sun at $74^{\circ} \mathrm{N}$ latitude. An average $50 \%$ reduction of insolation due to clouds was assumed, as suggested by data from Bjørnøya, provided by the Norwegian Meteorological Institute. Of this light, $50 \%$ was assumed to be usable for photosynthesis. A reflection loss of 5-10\%, dependent on the solar elevation, was used in the simulations.

The attenuation coefficient, $k$, of light in the water column is given below (Parsons et al. 1977):

$\mathrm{k}=\left\{\mathrm{k}_{\mathrm{w}}+0.0088 \mathrm{Chl}^{*}+0.054\left(\mathrm{Chl}^{*}\right)^{2 / 3}\right\} / \bar{\mu}$

where $k_{w}\left(m^{-1}\right)$ represents the attenuation coefficient for pure seawater, $\bar{\mu}$ is the average cosine of the light field, which has been set at 0.6 (Kirk 1983), and $\mathrm{Chl}^{*}$ is the concentration of lightabsorbing pigments calculated by the formula of Sakshaug \& Slagstad (1991):

$\mathrm{Chl}^{*}=\mathrm{Chl} a+1 / 2$ Phaeophytin

Based on data from the Barents Sea, Sakshaug \& Slagstad (1991) described the relationship between chlorophyll $a$ and phaeophytin as:

Phaeophytin $=0.45 \mathrm{Chl} a+0.02$

During the early spring, the copepod biomass is dominated by adult females of $C$. finmarchicus. In our model we have therefore simplified the copepod population to consist entirely of adult female C. finmarchicus. A detailed model of the grazing impact from this species, based on the energy requirements, has previously been published by Slagstad (1981) and Slagstad \& Tande (1990). The ingestion rate is determined by the population size and the clearance rate. The maximum clearance rate $\left(\mathrm{FR}_{\mathrm{m}}\right)$ for a copepod is (Slagstad \& Tande 1990):

$\mathrm{FR}_{\mathrm{m}}=\mathrm{FR}_{0} \mathrm{e}^{0.11 \mathrm{~T}}$

where $\mathrm{FR}_{0}$ is the maximum clearance rate 
Table 2. Summary of grazing-rate data, expressed as daily ration (carbon intake per day as percentage of copepod carbon content), for the large-sized copepods in the Barents Sea. Analysis techniques: gut-fluor = based on gut content of algal pigments (e.g. Mackas \& Bohrer 1976): ${ }^{14} \mathrm{C}=$ radiolabelling technique (e.g. Conover \& Francis 1973); Elzone $=$ in situ incubation and electronic particle counting (e.g. Båmstedt et al. 1985).

\begin{tabular}{|c|c|c|c|c|c|}
\hline Species & Stage & Period & $\begin{array}{l}\text { Daily } \\
\text { ration }\end{array}$ & $\begin{array}{l}\text { Analysis } \\
\text { technique }\end{array}$ & Reference \\
\hline Calanus finmarchicus & $c-1$ & May & $0-5.2$ & gut-fluor & Unpublished from 1987 \\
\hline C. finmarchicus & $c-I, I I$ & May-June & $4.9-148.5$ & ${ }^{14} \mathrm{C}$ & Unpublished from 1987 \\
\hline C. finmarchicus & c-ll & May & $0-1.7$ & gut-fluor & Unpublished from 1987 \\
\hline C. finmarchicus & c-11I & May & $0-1.9$ & gut-fluor & Unpublished from 1987 \\
\hline C. finmarchicus & c-III & May-June & $0.9-46.6$ & ${ }^{14} \mathrm{C}$ & Unpublished from 1987 \\
\hline C. finmarchicus & c-IV & May-June & $6.7-82.1$ & ${ }^{14} \mathrm{C}$ & Unpublished from 1987 \\
\hline C. finmarchicus & $c-V$ & May-June & $0.3-27.6$ & ${ }^{14} \mathrm{C}$ & Unpublished from 1987 \\
\hline C. finmarchicus & $c-V$ & May-June & $0.5-16.8$ & gut-fluor & Tande \& Båmstedt 1985 \\
\hline C. finmarchicus & $c-V$ & May-June & $0-14.9$ & gut-fluor & Unpublished from 1987 \\
\hline C. finmarchicus & ad. female & May-June & $0-15.4$ & gut-fluor & Unpublished from 1987 \\
\hline C. finmarchicus & ad. female & May-June & $2.8-32.0$ & gut-fluor & Tande \& Båmstedt 1985 \\
\hline C. finmarchicus & ad. female & May-June & $0.3-55.3$ & ${ }^{14} \mathrm{C}$ & Unpublished from 1987 \\
\hline Calanus glacialis & $\mathrm{c}-\mathrm{I}$ & July-Aug. & 75.0 & gut-fluor & Eilertsen et al. $1989 \mathrm{~b}$ \\
\hline C. glacialis & c-II & July-Aug. & 27.9 & gut-fluor & Eilertsen et al. $1989 \mathrm{~b}$ \\
\hline C. glacialis & c.III & July-Aug. & 15.1 & gut-fluor & Eilertsen et al. $1989 \mathrm{~b}$ \\
\hline C. glacialis & c-IV & July-Aug. & 58.4 & gut-fluor & Eilertsen et al. $1989 \mathrm{~b}$ \\
\hline C. glacialis & c-IV & May-June & $1.9-20.2$ & gut-fluor & Unpublished from 1987 \\
\hline C. glacialis & $\mathrm{c}-\mathrm{IV}$ & May-June & $1.8-10.6$ & ${ }^{14} \mathrm{C}$ & Unpublished from 1987 \\
\hline C. glacialis & $\mathrm{c}-\mathrm{IV}$ & May-June & $0.2-10.6$ & ${ }^{14} \mathrm{C}$ & Unpublished from 1987 \\
\hline C. glacialis & c-IV & May-June & $0.1-27.4$ & ${ }^{1+} \mathrm{C}$ & Unpublished from 1987 \\
\hline C. glacialis & $\mathrm{c}-\mathrm{IV}$ & May-June & 1.9 .4 .5 & gut-fluor & Tande \& Bảmstedt 1985 \\
\hline C. glacialis & c-IV & July & $2.0-21.2$ & gut-fluor & Hansen et al. $1990 \mathrm{a}$ \\
\hline C. glacialis & $\mathrm{c}-\mathrm{IV}$ & May-June & $0.1-11.5$ & Elzone & Unpublished from 1983 \\
\hline C. glacialis & $c-V$ & July & $2.6-29.9$ & gut-fluor & Hansen et al. 1990 a \\
\hline C. glacialis & $\mathrm{c}-\mathrm{V}$ & July & $1.7-79$ & gut-fluor & Unpublished from 1984 \\
\hline C. glacialis & $c-V$ & May-June & $0-24.0$ & gut-fluor & Unpublished from 1987 \\
\hline C. glacialis & $c-V$ & May-June & $0.8-13.9$ & gut-fluor & Tande \& Båmstedt 1985 \\
\hline C. glacialis & $\mathrm{c}-\mathrm{V}$ & May-June & $0.2-7.7$ & Elzone & Unpublished from 1983 \\
\hline C. glacialis & ad. female & May-June & $0-19.2$ & gut-fluor & Unpublished from 1987 \\
\hline C. glacialis & ad. female & May-June & $0.3-8.5$ & Elzone & Unpublished from 1983 \\
\hline C. glacialis & ad. female & May-June & $0.5-53.8$ & gut-fluor & Tande \& Bảmstedt 1985 \\
\hline Calanus hyperboreus & $\mathrm{c}-\mathrm{I}$ & July-Aug. & 67.9 & gut-fluor & Eilertsen et al. $1989 \mathrm{~b}$ \\
\hline C. hyperboreus & $\mathrm{c}-11$ & July-Aug. & 87.5 & gut-fluor & Eilertsen et al. 1989b \\
\hline C. hyperboreus & c-III & July-Aug. & 119.8 & gut-fluor & Eilertsen et al. $1989 \mathrm{~b}$ \\
\hline C. hyperboreus & c-IV & July-Aug. & 102.5 & gut-fluor & Eilertsen et al. $1989 \mathrm{~b}$ \\
\hline C. hyperboreus & $c-I V$ & July & $2.2-40$ & gut-fluor & Unpublished from 1984 \\
\hline C. hyperboreus & $\mathrm{c}-\mathrm{IV}$ & May-June & $0-7.6$ & ${ }^{1+} \mathrm{C}$ & Unpublished from 1984 \\
\hline C. hyperboreus & c-IV & May-June & $4.8-20.2$ & gut-fluor & Unpublished from 1987 \\
\hline C. hyperboreus & $\mathrm{c}-\mathrm{V}$ & May-June & $0.5-36.0$ & gut-fluor & Unpublished from 1987 \\
\hline C. hyperboreus & $c \cdot V$ & May-June & $1.2-2.4$ & Elzone & Unpublished from 1983 \\
\hline C. hyperboreus & $c \cdot V$ & May-June & $0.2-3.8$ & ${ }^{14} \mathrm{C}$ & Unpublished from 1984 \\
\hline C. hyperboreus & ad. female & May-June & $0.3-17.4$ & ${ }^{14} \mathrm{C}$ & Unpublished from 1984 \\
\hline C. hyperboreus & ad. female & May-June & $2.4-22.1$ & gut-fluor & Unpublished from 1987 \\
\hline Calanus spp. & c-II & July & $18.2-72.7$ & gut-fluor & Hansen et al. 1990a \\
\hline Calanus spp. & c-III & July & $14.6-63.7$ & gut-fluor & Hansen et al. $1990 \mathrm{a}$ \\
\hline Metridia longa & ad. female & May-June & $0.2-6.3$ & ${ }^{14} \mathrm{C}$ & Unpublished from 1987 \\
\hline M. longa & ad. female & May-June & $0-3.8$ & gut-fluor & Unpublished from 1987 \\
\hline
\end{tabular}

$\left(\mathrm{ml} \mathrm{h}^{-1}\right)$ at a temperature $(\mathrm{T})$ of $0^{\circ} \mathrm{C}$. We used a temperature of $3^{\circ} \mathrm{C}$ in the model simulations. The parameter value of $\mathrm{FR}_{0}$ for adult female C. finmarchicus varies from $4.2 \mathrm{ml} \mathrm{h}^{-1}$ (Huntley 1981) to $12 \mathrm{ml} \mathrm{h}^{-1}$ (Tande \& Båmstedt 1985). We have used the value $10.0 \mathrm{ml} \mathrm{h}^{-1}$ throughout our simulations. An index of electivity (E; Ivlev 1961, cited in Valiela 1984) was used in some of the simulations, in order to define a preference towards diatoms, in accordance with current the- 
ory (cf. Verity \& Smayda 1989)

$E=\left(r_{i}-p_{i}\right) /\left(r_{i}+p_{i}\right)$

where $r_{i}$ is the proportion of species $i$ in the diet and $\mathrm{p}_{\mathrm{i}}$, the corresponding proportion in the food environment.

The energy requirements for a spawning $C$. finmarchicus female is taken to be $20 \mu \mathrm{g} \mathrm{C} \mathrm{d}^{-1}$ (egg production from Hirche 1990; gross growth efficiency from Peterson 1988). This gives a critical food concentration of $83 \mathrm{mg} \mathrm{C} \mathrm{m}^{-3}$.

\section{Results and discussion}

\section{Daily rations of the copepods}

The compiled data on grazing rate of the largesized copepods (Table 2) cover the season from May to August, i.e. most of the production period of the year. The data are expressed as daily rations (carbon intake as percentage of the body-bound carbon) and are given either as ranges or as mean values, dependent on the data available from the different sources. Most of the data are for older developmental stages, and these may also be considered most reliable. If the median values are used from those studies where ranges are given, and used together with the displayed mean values, a representative average value for each species and stage can be calculated. These values are given below: as given by the ${ }^{14} \mathrm{C}$-technique (Table 2), may reflect a greater technical difficulty with the smallest organisms in the analytical procedures. The displayed values given for the early copepodite stages above, especially for $C$. hyperboreus, might therefore be somewhat biased. Nevertheless, considering the total information given in Table 2, the daily ration of copepodite stages I-IV appears significantly higher than that of for the older stages. This has subsequently been confirmed for C. finmarchicus from Balsfjorden, northern Norway, in laboratory experiments with Thalassiosira nordenskioldii and Phaeocystis pouchetii as food, two algal species that are commonly predominant in the Barents Sea (Hansen et al. 1990b).

The low values on daily rations of Metridia longa (Table 2) indicate that this species does not graze solely on phytoplankton. Data from Balsfjorden, northern Norway (Båmstedt et al. 1985), the west coast of Norway (Båmstedt \& Ervik 1984) and the west coast of Sweden (Båmstedt \& Tande 1988) all indicate an omnivorous trophic state of this copepod.

\section{Individual variability in grazing rate}

In a previous paper by Båmstedt (1988) the individual variability of copepod bioenergetics was focused upon and explained by a suggested variable nutritional history. The present study gives a comparable example from the Barents Sea, original data from July 1984 on gut fullness of

\begin{tabular}{lllcccc}
\hline Species/Stage & c-I & c-ll & c-lll & c-IV & c-V & c-Vl \\
\hline Calanus finmarchicus & 40.3 & 39.5 & 25.2 & 44.4 & 10.0 & 17.6 \\
Calanus glacialis & 75.0 & 27.9 & 15.1 & 14.5 & 16.0 & 13.7 \\
Calanus hyperboreus & 67.9 & 87.5 & 119.8 & 35.0 & 7.4 & 10.6 \\
Metridia longa & - & - & - & - & - & 2.6 \\
\hline
\end{tabular}

Excluding Metridia longa, the displayed values indicate that the oldest developmental stages (c$\mathrm{V}, \mathrm{c}-\mathrm{VI}$ ) have a typical daily ration of $7-18 \%$, whereas the younger copepodite stages may reach $100 \%$ or more. The highest original figures in Table 2 were given for Calanus hyperboreus, taken from Eilertsen et al. (1989b). They used a published single value for the gut evacuation rate of all copepods, and the gut fullness of c-I, c-II and c-III $C$. hyperboreus was only estimated from similar-sized copepodite stages of $C$. glacialis. Furthermore, the very wide range in daily rations for the early copepodite stages of $C$. finmarchicus, copepodite stage IV Calanus hyperboreus (Fig. 1 ). In the extreme case, shown by copepods from $40 \mathrm{~m}$ depth, the individual variability covered a range from 12 to $340 \mathrm{ng}$ pigment individual ${ }^{-1}$, i.e. a factor of 28 in difference between lowest and highest value. By considering these results, together with the curve for in situ fluorescence, it is obvious that food availability alone explains neither the individual variability nor the variation with depth. However, high individual variability may be caused by non-synchronous individual rhythms in feeding, as suggested for $C$. glacialis by Båmstedt (1984), and this may in turn be 
Gut contents (ng chl. a equiv. copepod-I)

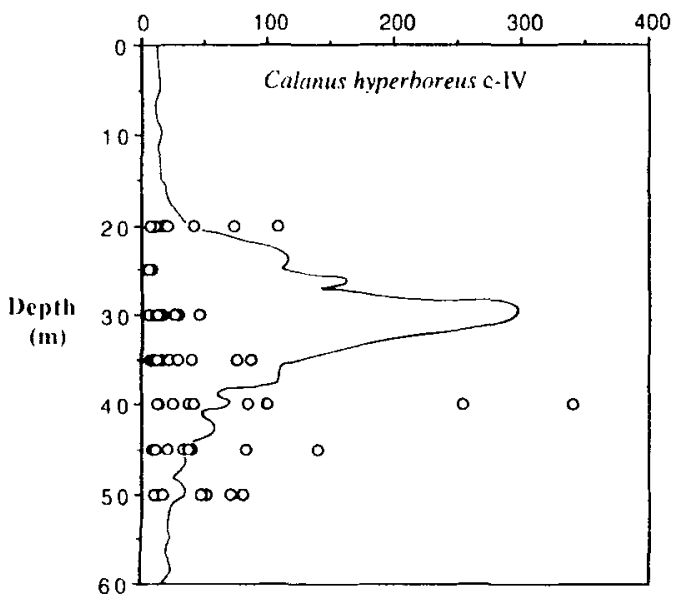

Fig. 1. Calanus hyperboreus c-IV. July 1984. Gut contents of algal pigments (chlorophyll $a+$ phaeophytin), measured on single individuals, as related to depth and relative phytoplankton distribution (shape of in situ fluorescence profile given). governed by the nutritional history of the individual copepod.

\section{Diurnal variation in feeding}

Published information on possible diel rhythms in feeding activity of the large-sized Arctic copepods suggests the absence of a rhythm during the light season with the midnight sun (Båmstedt 1984; Hansen et al. 1990a; Båmstedt \& Skjoldal unpubl. data) but a pronounced diurnal cycle in late summer, with maximum ingestion during the dark period of the day (Head et al. 1985). Our results for Calanus hyperboreus c-IV and $C$. glacialis $\mathrm{c}-\mathrm{V}$ from July 1984 are based on samples consisting of 10 individually analysed copepods (Fig. 2). For the first species, highest gut contents were recorded in the afternoon, but the temporal variation was relatively small in relation to the individual variability at each depth and between depths. C. glacialis showed pronounced vertical

Fluorescence (V)

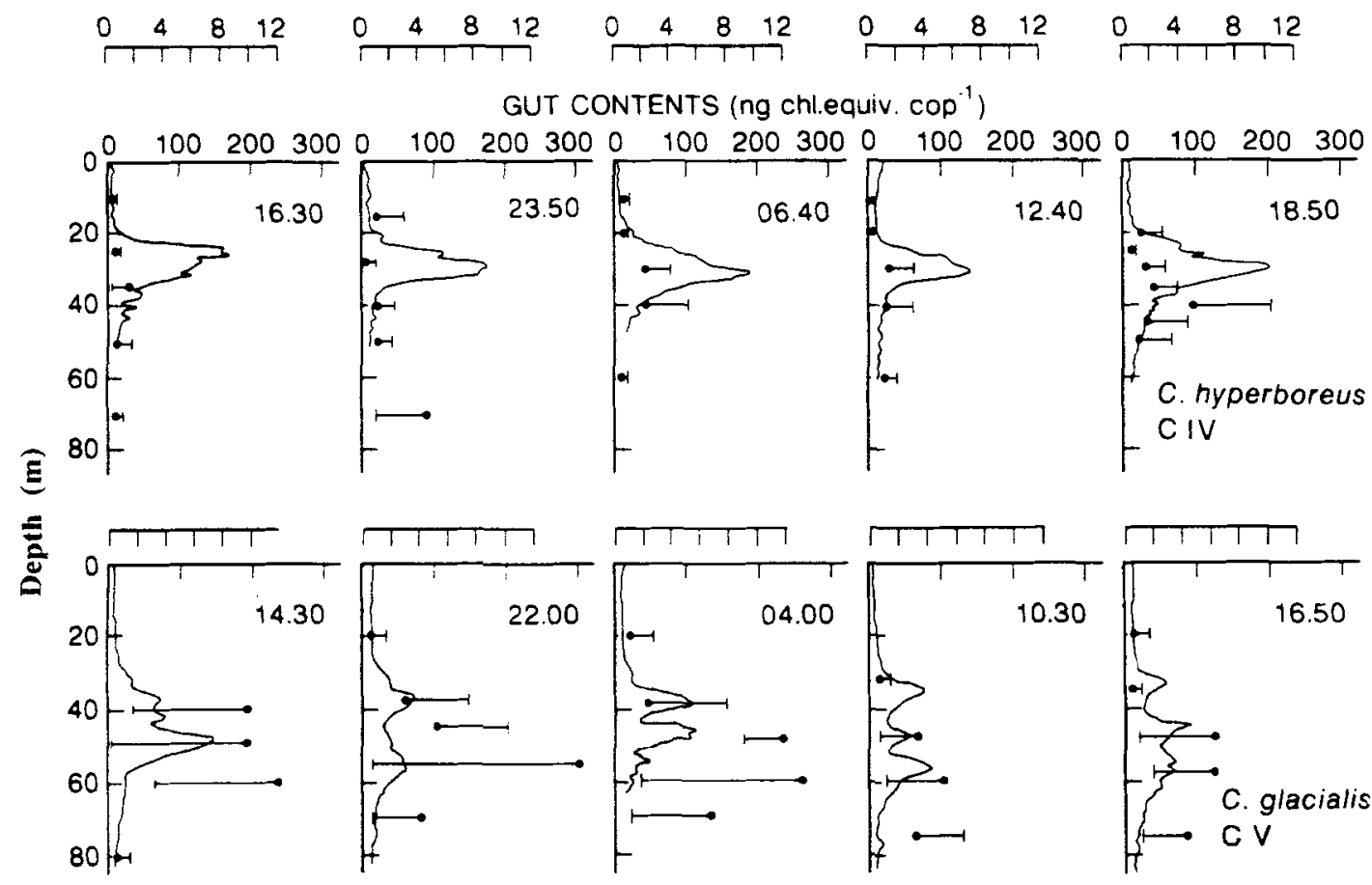

Fig. 2. Calanus hyperboreus c-IV and C. glacialis c-V. Vertical profiles of grazing rate (mean and $\mathrm{SE},+$ or - ) of copepods sampled 5 times during a 24-hour period in July 1984. Each point represents 10 individually analysed copepods. The displayed curve represents relative in situ fluorescence (in volts). 
Fig. 3. Calanus

finmarchicus and $C$. glacialis. Copepod grazing rate versus depth of occurrence. The data from May-June 1987 represent vertical profiles from up to 8 different localities, and the wide ranges have necessitated the use of a logarithmic scale. ng pigment (mg protein)-1 $h^{-1}$

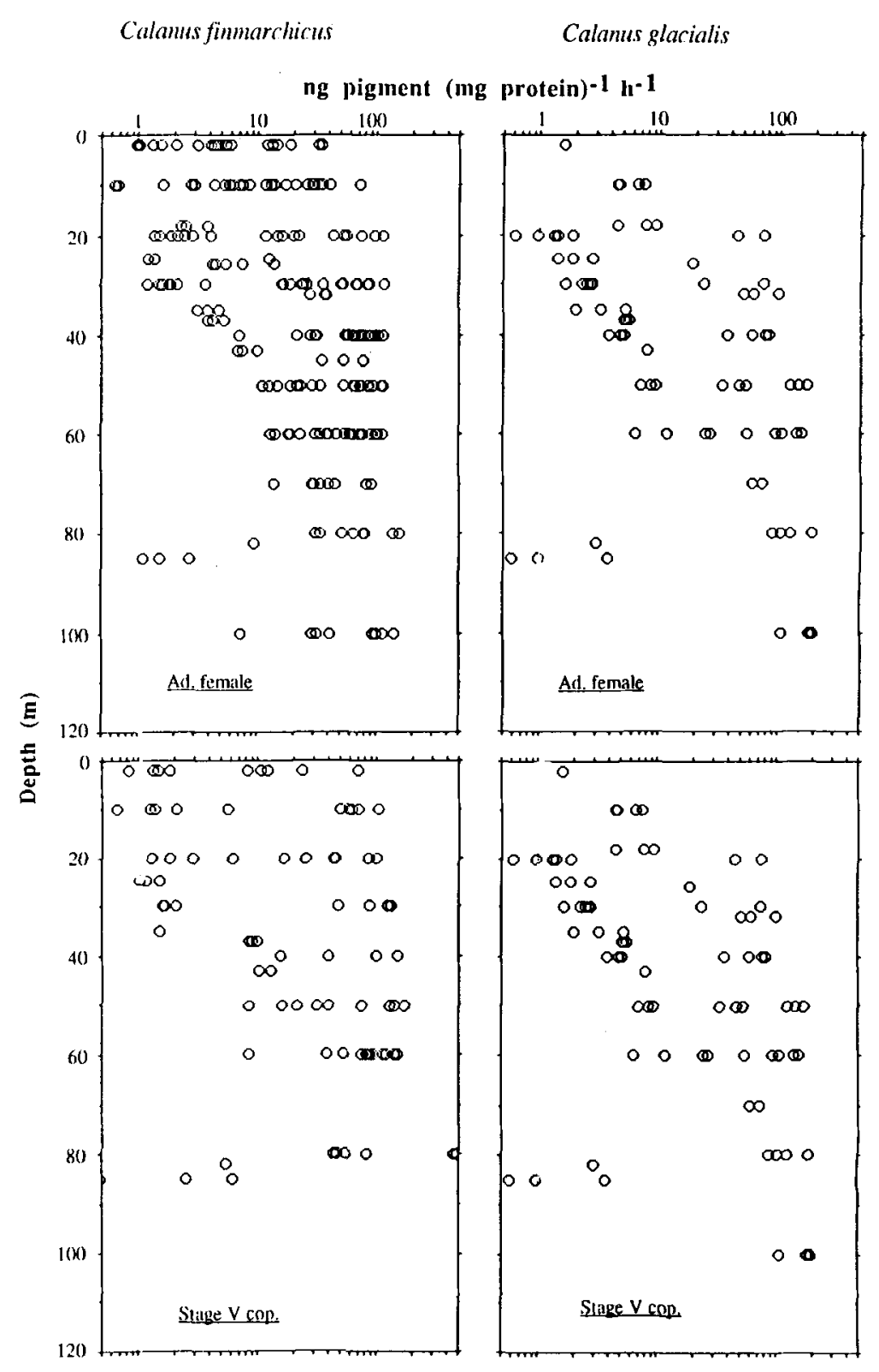

variation in gut fullness, together with high individual variability. The data therefore support the suggestion that there is no diel rhythm in copepod grazing rate during the summer in the Barents Sea.

\section{Grazing in relation to depth}

Reduced copepod gut contents with depth of occurrence has previously been reported from the Barents Sea for Calanus finmarchicus and C. glacialis (Båmstedt 1984; Tande \& Båmstedt 1985). New grazing-rate data for these two species, collected during a cruise in May-June 1987 (Båmstedt \& Skjoldal unpubl. data) have been plotted versus the depth of sampling (Fig. 3 ). The data represent results from 8 different stations, classified either as mid-bloom or postbloom situations. A logarithmic scale has been used in order to get as high a resolution as possible 
of the data. The scatter in the data is very high, irrespective of species or developmental stage, and there is obviously no simple relationship between weight-specific grazing rate and depth of occurrence. This will be further discussed in the section below.

\section{Grazing rate in relation to environmental factors}

Several investigators have tried to find a simple and close relationship between the amount of available food and the feeding rate of copepods, as is typically found in laboratory experiments (e.g. Frost 1972; Kiørboe et al. 1982; Hansen et al. 1990b). These attempts have generally failed, both when food has been expressed in terms of particulate protein or carbohydrate (Båmstedt 1984) and when expressed as chlorophyll $a$ (Boyd et al. 1980; Dagg \& Grill 1980; Dagg \& Wyman 1983; Head et al. 1985, 1988; Tande \& Bămstedt 1985; Hansen et al. 1990a). However, Huntley (1981), using shipboard incubations, found highly significant relationships $\left(\mathrm{r}^{2}\right.$ varying from 0.949 to 0.961 ) between the concentration of natural phytoplankton and grazing rate of the three Arctic Calanus species.

In laboratory experiments where the functional relationship of grazing rate to food concentration is recorded, copepods are exposed to different concentrations of homogeneous food, everything else being constant. Such a simple situation is probably not found in the natural habitat and Huntley (1988) lists 7 forcing functions for the net response of Calanus to its current environment. Five of these functions (light, body weight, temperature, food concentration and food size) can easily be quantified, whereas two of them (food quality and feeding history) are more difficult to handle quantitatively. Possible effects on Calanus of the two latter factors have been reviewed by Huntley (1988), and we will return to food quality in a later section and concentrate on purely quantitative environmental factors here.

Data on environmental parameters and copepod grazing from a cruise in the Barents Sea in May-June 1987 (Båmstedt \& Skjoldal unpubl. data) have been taken both from stations where the spring phytoplankton bloom was intense (midbloom situation) and from stations where the bloom had terminated (post-bloom situation). The mid-bloom stations had a constant salinity with depth, ranging from 35.00 to $35.10 \%$ and temperature usually between 1.3 and $2.2^{\circ} \mathrm{C}$, indicating Atlantic Water. A strong nutricline at 40

Nutrient concentration $\left(m m^{-3} m^{-3}\right.$ Nutrient concentration $\left(m m^{-3} m^{-3}\right.$ Pigment concentration $\left(m g m^{-3}\right)$
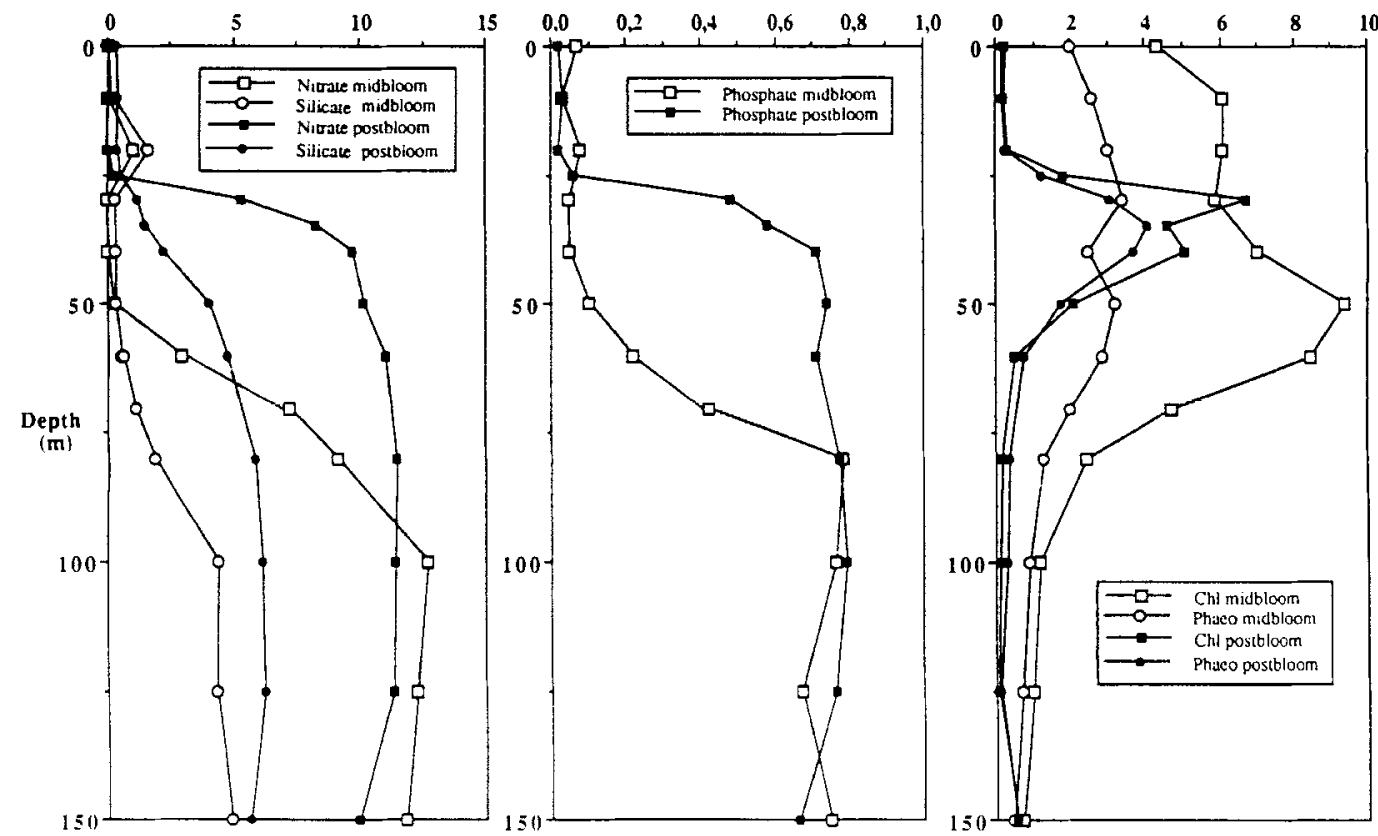

Fig. 4. May-Junc 1987. Vertical profiles of nutrients (nitrate and silicate), chiorophyll $a$ and phacopigments at Stns. 923 (midhloom station) and 961 (post-bloom station). Data from Båmstedt \& Skjoldal (unpubl.). 

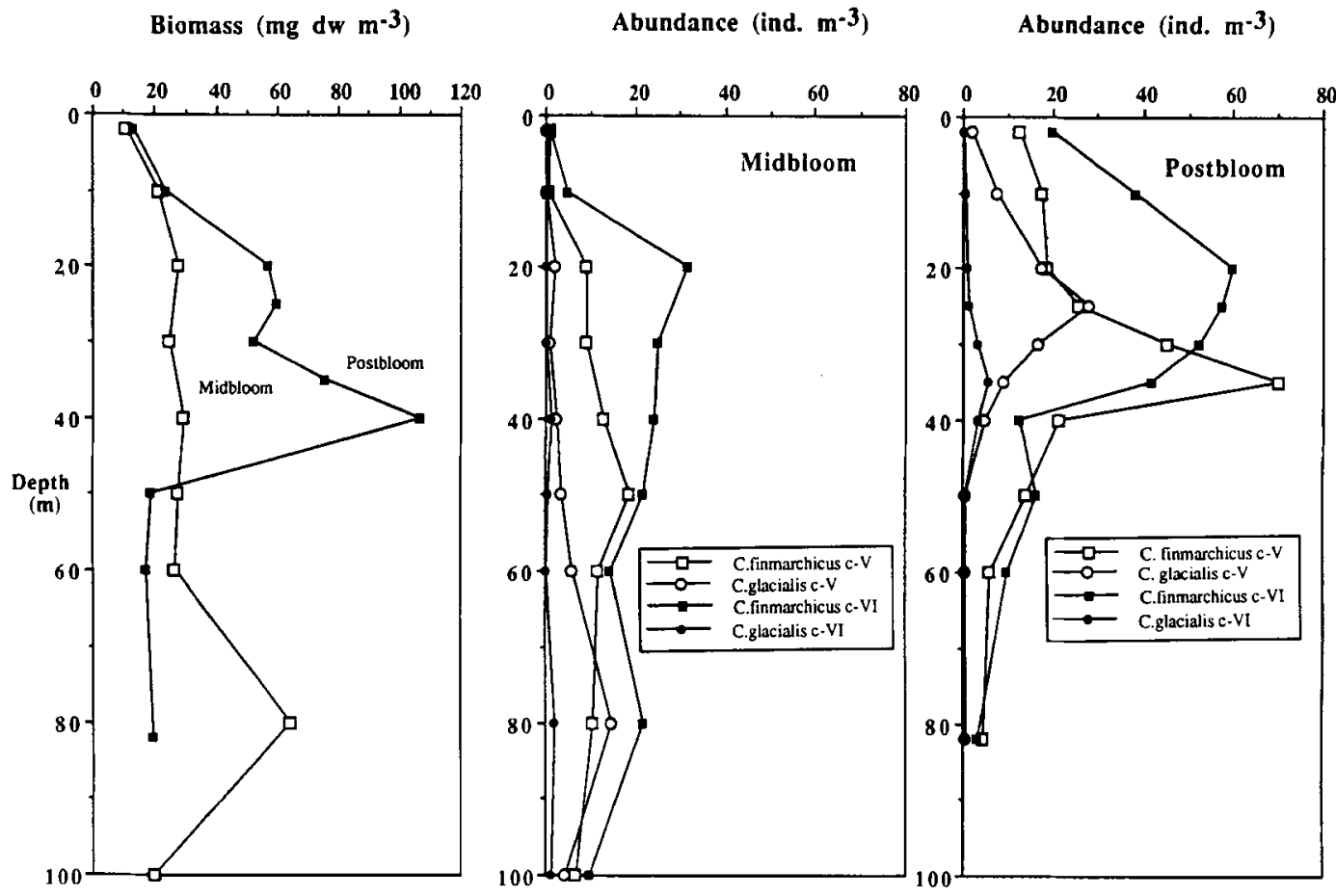

Fig. 5. May-June 1987. Vertical distribution of total zooplankton biomass (collected by a $200 \mu \mathrm{m}$ mesh net) and abundance of adult females and stage $V$ copepodites of Calanus finmarchicus and $C$. glacialis at Stns. 923 (mid-bloom station) and 961 (postbloom station). Data from Båmstedt \& Skjoldal (unpubi.).

to $60 \mathrm{~m}$ depth, with reduced concentrations of nitrate, phosphate and silicate above this, and with high chlorophyll $a$ concentrations down to at least $60 \mathrm{~m}$ depth, including a pronounced subsurface maximum, were common features for these stations. Fig. 4 gives one example by showing the vertical profiles at Station 923, which was a typical mid-bloom station. The post-bloom stations were all influenced by Arctic Water of low salinity and temperature in the surface, the salinity distribution defining a strong pycnocline at about $30 \mathrm{~m}$ depth. Typically, nutrients were completely depleted above the pycnocline, and the nutricline therefore corresponded well with the pycnocline. The chlorophyll $a$ concentration was low in the nutrient-poor surface waters, while there was a maximum at 25 to $50 \mathrm{~m}$ depth. Station 961 is given as an example in Fig. 4.

The zooplankton biomass and abundance of copepods, as exemplified by adult females and copepodite stage V Calanus finmarchicus and $C$. glacialis, differed between mid-bloom and postbloom stations. Biomass and abundance were both fairly constant at depths down to $100 \mathrm{~m}$ in the mid-bloom stations, except for the reduced values in the surface water (Fig. 5, from Station 923). Biomass and abundance were commonly higher in the post-bloom stations, with a pronounced subsurface maximum at depths from 20 to $60 \mathrm{~m}$ (Fig. 5, from Station 961).

The grazing rate of copepods, here exemplified by adult females and stage $V$ copepodites of C. finmarchicus and C. glacialis from two stations, showed great variability at all sampling depths (Fig. 6, from Stns. 923 and 961, respectively). However, the grazing rate was considerably higher in the mid-bloom situation, with maximum values close to $160 \mathrm{ng}$ pigment $\mathrm{mg}^{-1}$ protein $\mathrm{h}^{-1}$, than in the post-bloom situation, where the grazing rate did not exceed $25 \mathrm{ng}$ pigment $\mathrm{mg}^{-1}$ protein $\mathrm{h}^{-1}$. Reduced grazing rate was also recorded in the surface water, and there was a pronounced subsurface maximum especialiy in the post-bloom situation, situated at $40-50 \mathrm{~m}$ depth, closely below the chlorophyll maximum.

The above grazing-rate data have been evaluated against biotic and abiotic environmental conditions through linear stepwise regression analyses, separating stations defined as midbloom situation and post-bloom situation, 
Grazing rate ( $\mathrm{ng} \mathrm{Chl}$ a equiv. (mg protein) $)^{-1} \mathrm{~h}^{-1}$ )

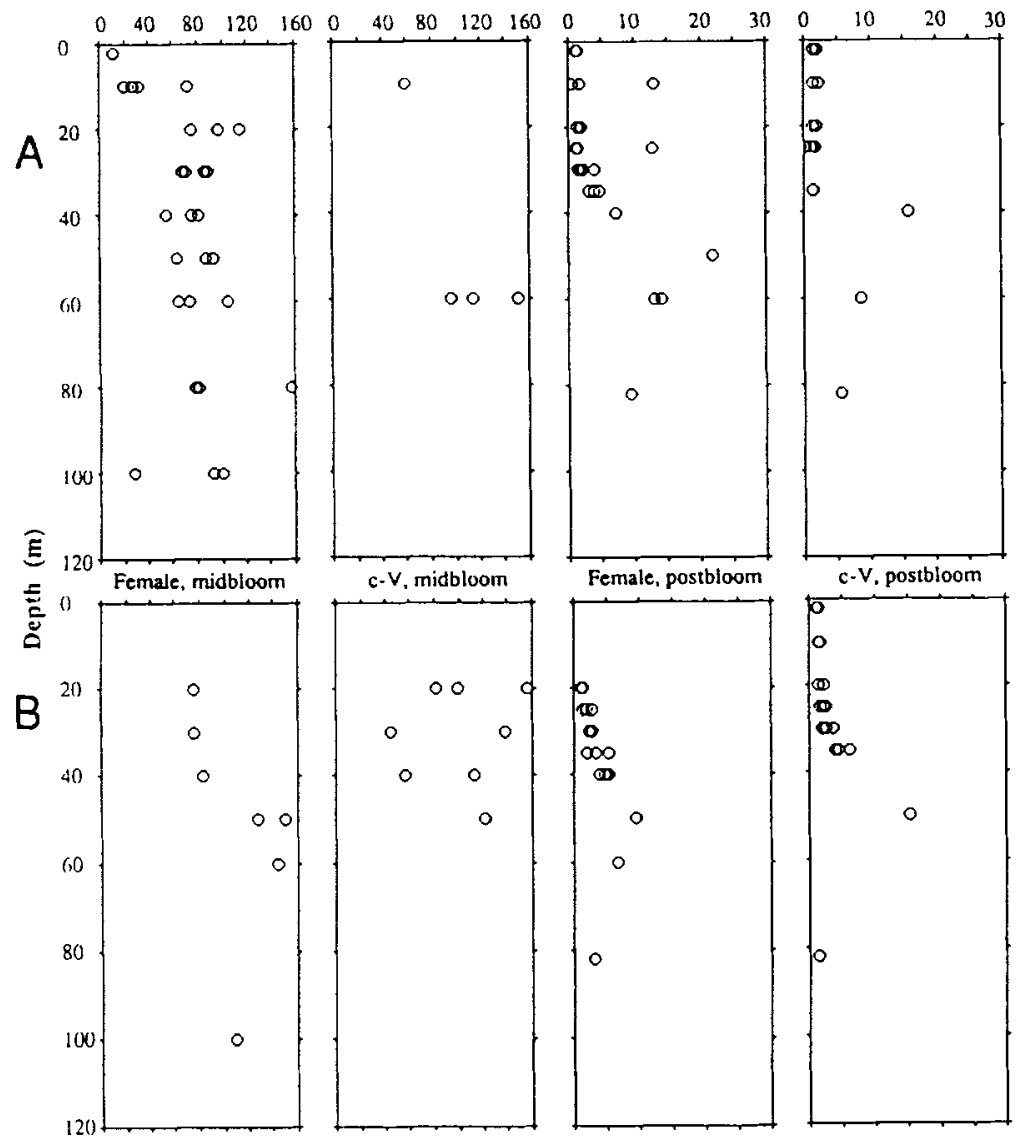

Fig. 6. Calanus

finmarchicus (A) and C. glacialis (B), May-Junc 1987. Vertical profiles of weight-specific grazing rate of copepodite stage $V$ and adult females. The midbloom situation is represented by Stn. 923 and the postbloom situation by Stn. 961 . Data from Båmstedt \& Skjoldal (unpubl.).

Table 3. Calanus finmarchicus and $C$. glacialis. Results of stepwise regression analysis on grazing rate (ng $\mathrm{Chl} a$ equiv. $\mathrm{mg}^{-1} \mathrm{protein}$ $\mathrm{h}^{-1}$ ) versus four independent variables (depth in $\mathrm{m}$, chlorophyll a concentration in $\mathrm{mg} \mathrm{m}^{-3}$, primary production in $\mathrm{mg} \mathrm{C}^{-3} \mathrm{~d}^{-1}$. and water density in sigma-t) of stage $V$ copepodites and adult females. The $F$-values from the statistical analysis are given, and those variables with F-values exceeding 4.0 (marked by an asterisk) have been included in the regression equations, which resulted in the displayed determination coefficient $\left(\mathbf{R}^{2}\right)$.

\begin{tabular}{|c|c|c|c|c|c|}
\hline Period/Stage & Depth & Chl. $a$ & Prim. prod. & Density & $\mathbf{R}^{2}$ \\
\hline \multicolumn{6}{|l|}{ Calanus finmarchicus } \\
\hline Stage $V$ copepodites & $7.03^{*}$ & $15.39^{*}$ & 0.91 & $29.91^{*}$ & 0.743 \\
\hline Adult females & $47.89^{*}$ & $5.41^{*}$ & $18.30^{*}$ & $12.93^{*}$ & 0.823 \\
\hline \multicolumn{6}{|l|}{ Postbloom } \\
\hline Stage V copepodites & 2.44 & $58.96^{*}$ & 0.48 & $12.86^{*}$ & 0.826 \\
\hline Adult females & 0.28 & $14.81^{*}$ & 0.47 & $22.54^{*}$ & 0.296 \\
\hline \multicolumn{6}{|l|}{ Calanus glacialis } \\
\hline \multicolumn{6}{|l|}{ Midbloom } \\
\hline Stage V copepodites & 2.77 & 0.18 & 0.01 & $106.97^{*}$ & 0.764 \\
\hline Adult females & 0.08 & 0.37 & 0.72 & $11.39^{*}$ & 0.655 \\
\hline \multicolumn{6}{|l|}{ Postbloom } \\
\hline Stage $V$ copepodites & 2.90 & 0.44 & 0.49 & 3.80 & -- \\
\hline Adult females & 1.37 & 1.21 & 0.96 & 3.29 & - \\
\hline
\end{tabular}


respectively, in two sets of data (Table 3). We selected two biotic variables reflecting the food environment (chlorophyll $a$ concentration and primary production) and two abiotic variables (depth and sigma-t of the water) that are commonly found to be important for the behaviour of the copepods.

The chlorophyll $a$ concentration and density distribution contributed significantly $(F>4.0)$ in explaining the grazing rate of $C$. finmarchicus in mid-bloom and post-bloom situations. Depth contributed significantly in two cases and primary production in a single case for $C$. finmarchicus (Table 3). For C. glacialis density was the only independent variable that showed a significant contribution, and in the post-bloom situation none of the four variables showed an F-value exceeding 4.0.

The results show that the relationship between the environmental condition and copepod feeding intensity is not usually a simple one. The visual impression from the graphs indicates that maximum grazing rate tends to occur somewhat below the chlorophyll maximum, and data transformation might therefore have improved the correlations. However, our main purpose was to evaluate if a simple relationship existed in the natural habitat, with a direct coupling between environmental factors and the grazing rate. Our data indicate that the chlorophyll distribution and water density usually govern the grazing rate of copepods, although much of the variability in grazing rate is not explained by these two factors.

\section{Grazing selectivity}

A selective grazing behaviour of zooplankton may force the phytoplankton species succession and therefore may be considered a major structuring ecological factor. From the early considerations where cell size and concentration of microalgae were the main regulating factors (e.g. Frost 1972) feeding behaviour and importance of food quality have been major components in the explanation of grazing control (see e.g. Huntley 1988 and references therein). More recently, attention has also been put to toxicity and unpalatability of algae in Scandinavian and Arctic waters (Huntley et al. 1987; Tande \& Båmstedt 1987; Nielsen et al. 1990; Estep et al. 1990). In the Barents Sea, where Phaeocystis pouchetii usually constitutes a major part of the phytoplankton community (Eilertsen et al. 1989a and unpubl. results), a suggested inhibitory effect on copepod grazing by this species (e.g. Dagg et al. 1982; Schnack et al. 1985; Claustre et al. 1990) may have severe consequences upon the development of the phytoplankton community. However, recent studies on copepod grazing, where the dominant Calanus species from the Barents Sea have been used, do indicate active grazing upon $P$. pouchetii (Tande \& Båmstedt 1987; Huntley et al. 1987; Eilertsen et al. 1989b). An explanation for this conflict between investigators was given by Estep et al. (1990) who suggested that the physiological condition of the algal colonies determines the palatability for grazers. Their results indicated inhibitory effects upon grazing when the colonies were healthy, but very high grazing rates on susceptible colonies. Such a change with age of algal cells has also been reported for the bloom-forming haptophycean flagellate Chrysochromulina polylepis (Nielsen et al. 1990).

\section{Simulation results}

During the spring the mixed layer may vary from $20 \mathrm{~m}$ near the ice border to more than $100 \mathrm{~m}$ in the Atlantic Water. Fig. 7A shows that the population succession of diatoms and Phaeocystis pouchetii when no grazing occurs, is influenced when using alternatively $25 \mathrm{~m}, 40 \mathrm{~m}$ and $75 \mathrm{~m}$ as mixed depth. Diatoms will gradualiy dominate in the first two cases, whereas $P$. pouchetii is better adapted than diatoms to the situation with $75 \mathrm{~m}$ mixed depth. Figure $7 \mathrm{~B}$ shows that the relative initial concentration is of great significance for the balance between the two algal forms. With two times higher initial concentration of diatoms $\left(\mathrm{P}_{0}=0.5 \times \mathrm{D}_{0}\right) P$. pouchetii stabilises at a low level, whereas diatoms increase exponentially. With higher initial concentrations of $P$. pouchetii $\left(P_{0}=2 \times D_{0}\right.$ resp. $\left.4 \times D_{0}\right)$, a dominance of $P$. pouchetii colonies will be established (Fig. 7B).

The distribution of the grazing pressure from 2,000 adult females Calanus finmarchicus has a significant influence on the algal community succession (Fig. 7C). With only a slight preference towards diatoms $(E=0.2)$ total algal biomass will be low and slightly dominated by diatoms. A stronger preference towards diatoms $(E=0.4$ and 0.9 , respectively) generates a correspondingly higher dominance of $P$. pouchetii. In the case with very strong preference towards diatoms $(E=$ 0.9 ), the critical diatom concentration for triggering production of $P$. pouchetii colonies is not 

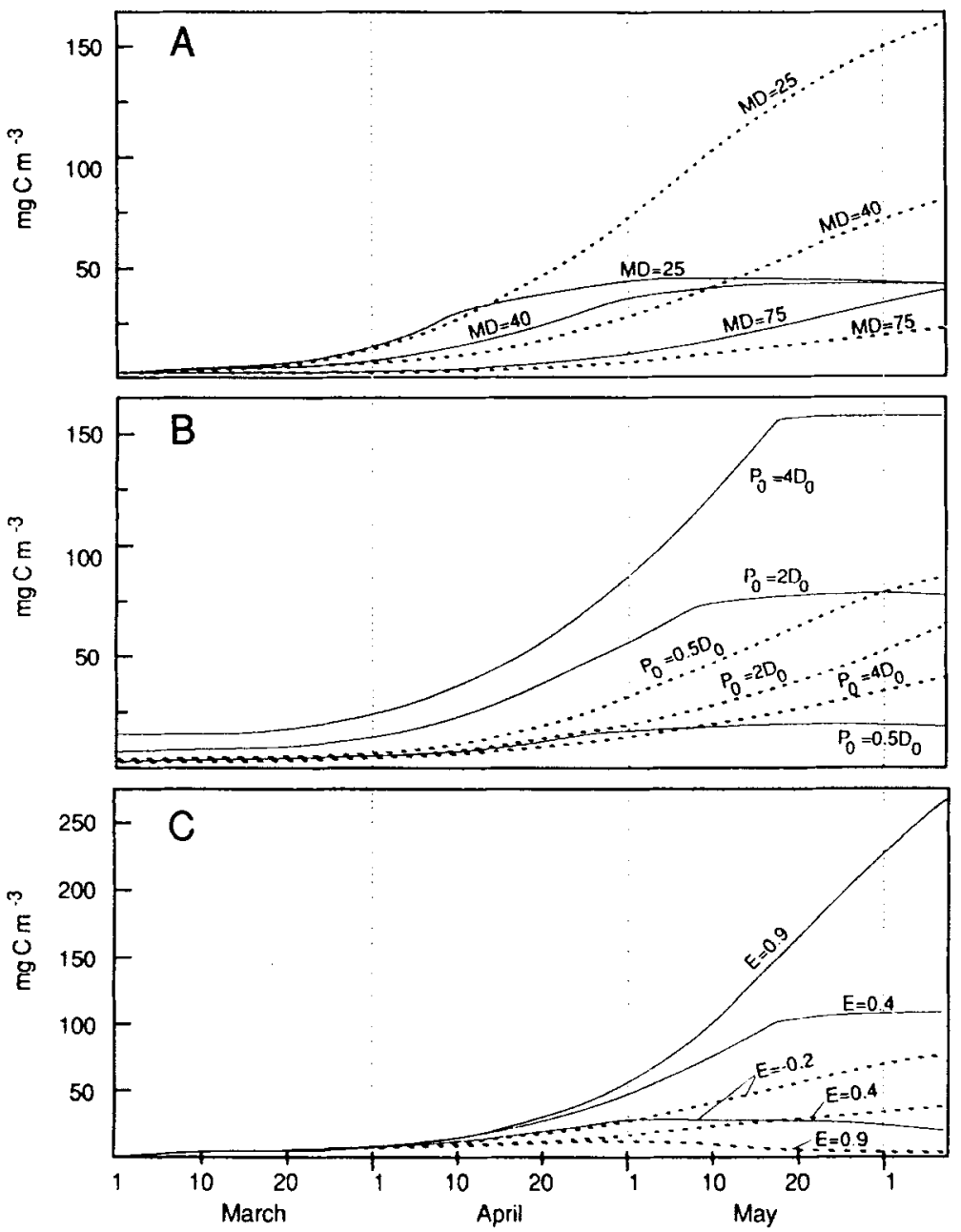

Fig. 7. Simulated population succession (mg $\left.\mathrm{C}^{-3}\right)$ in a community with diatoms (broken lines) and Phaeocystis pouchetii (solid lines) with defined $\mu$ and $\alpha^{c}$ (see (ext). A. No grazing but variable extent of the mixed layer $(75,40$ and $25 \mathrm{~m}$ ). B. No grazing but variable initial ratio between biomass of $P$. pouchetii and diatoms $\left(\mathrm{P}_{0} / \mathrm{D}_{0}=0.5 ; 2.0 ; 4.0\right)$. C. Grazing by 2000 adult female Calanus finmarchicus with variable preference towards diatoms $(E=-0.2 ; 0.4$; 0.9 ). reached and production of $P$. pouchetii solitary cells is exponential (Fig. 7C). However, solitary cells of $P$. pouchetii are usually not found in concentrations higher than $0.5 \mathrm{mg} \mathrm{Chl} a \mathrm{~m}^{-3}$ (40 $\mathrm{m} \mathrm{C} \mathrm{m}^{-3}$, Eilertsen unpubl. results). Microzooplankton grazing may account for this discrepancy. Thus, T. Dale (pers. comm.) found that the ciliates rapidly increased their biomass during the spring bloom in the Barents Sea, and Eilertsen (unpubl. results) found a high phaeopigment/Chl $a$ ratio (ranging from 0.3 to 2.3) during times with dominance of $P$. pouchetii solitary cells. Due to lack of quantitative data on this problem, we have not included it in our model.

None of the above simulations indicate any fast succession in spring towards an extensive dominance of $P$. pouchetii colonies in high concentrations. Preliminary studies in the laboratory (Eilertsen unpubl. results) indicate that the growth characteristics of $P$. pouchetii may be more competitive than shown by Verity et al. (1991 this volume). We have therefore simulated the succession with three alternative values for $\mu$ and $\alpha^{C}$ for the colonial form of $P$. pouchetii (Fig. $8 \mathrm{~A}$ and $\mathrm{B}$ ) where the lowest values represent those given by Verity et al. (1991). The simulation assumes a slight grazing selectivity towards diatoms $(E=0.2)$ from 2000 copepods. The simulation results show that, under the conditions given, $P$. pouchetii can hardly maintain a high dominance over diatoms with the established growth parameters. An increase in $\mu$ or $\alpha^{C}$ changes this situation considerably, and with a 
Fig. 8. Simulated population succession (mg $\mathrm{C} \mathrm{mg}^{-3}$ ) in a community with diatoms (broken lines) and Phaeocystis pouchetii (solid lincs), mixed depth $=40 \mathrm{~m}$ and grazing by 2000 adult females Calanus

finmarchicus with $\mathrm{E}=\mathbf{0 . 2}$ (slight preference towards diatoms). A. Variable growth parameter $\mu(0.22$; $0.33 ; 0.46$ ) for the colonial forms of $P$. pouchetii. B Variable growth parameter $\alpha^{\mathrm{C}}(0.0003 ; 0.0006$; 0.0009 ) for the colonial forms of $P$. pouchetii.
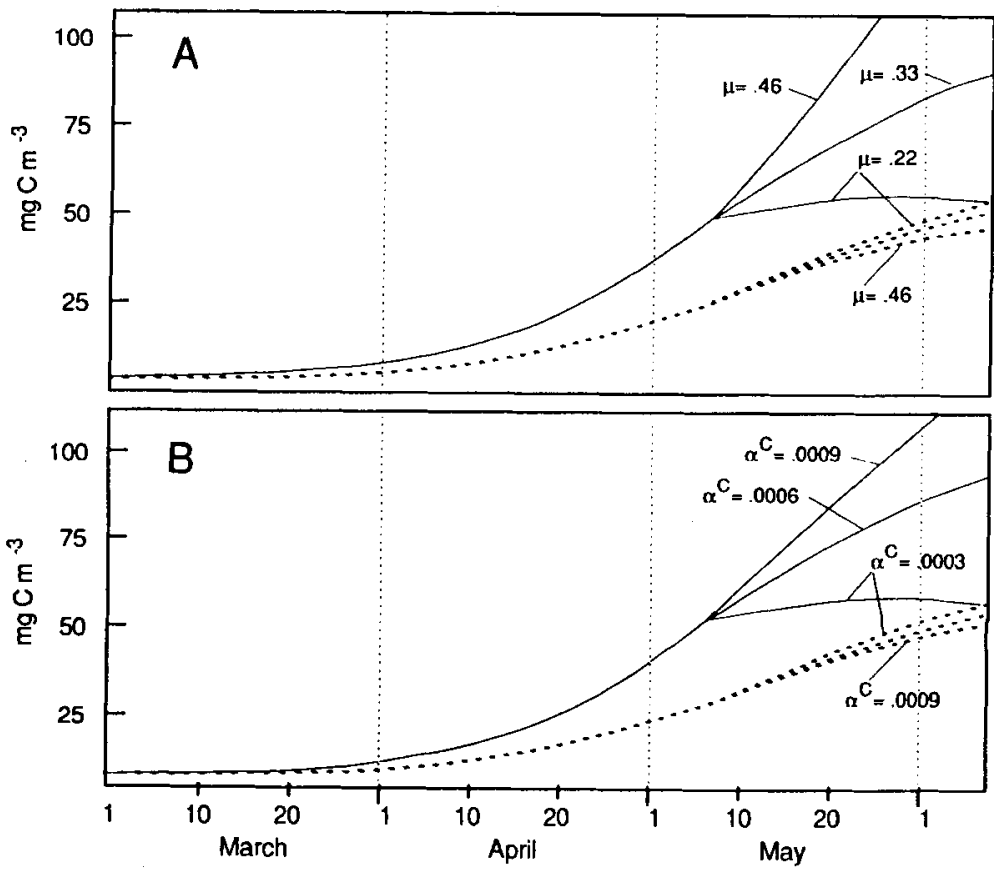

combined increase of both parameters the potential for a rapid development of a heavy bloom of $P$. pouchetii colonies is given.

The simulation results indicate that vertical stratification and grazing by zooplankton are variables of great significance for the numerical balance between diatoms and $P$. pouchetii. The occurrence of two different modes of $P$. pouchetii and lack of knowledge about the mechanisms involved in the production of these forms complicate the picture. The small solitary fiagellates have a size of 3-8 $\mu \mathrm{m}$ (Tande \& Båmstedt 1987) which indicate low retention efficiency for copepods (cf. Berggren et al. 1988). Microzooplankton can graze upon these with high efficiency (Johnsson 1986), whereas the macrozooplankton grazing on Phaeocystis colonies still is controversial (see above). Therefore, identification of the main micrograzers and quantitative measurements of microzooplankton grazing on microflagellates is an area which should render high priority in future ecological investigations in the Barents Sea. Furthermore, the importance of specific properties of $P$. pouchetii also needs much more attention. This includes a positive buoyancy of especially large colonies of $P$. pouchetii (Skreslet 1988), inhibitory effects on its own growth in dense populations (Kayser 1970) and release of dissolved organic matter (Bätje \& Michaelis 1986) that may affect growth of microalgae. None of these aspects have been included in our model formulation.

Acknowledgements. - We thank all the colleagues that have contributed in the field work and laboratory work during the cruises, experiments and analyses from which the resuits in this paper were produced. We thank P. Verity for constructive critique. We also thank the organisers of the research program, the Norwegian Fisheries Research Council and the Ministry of the Environment for the very stimulating period with Pro Mare.

\section{References}

Båmstedt, U. 1984: Diel variation in the nutritional physiology of Calanus glacialis from lat. $78^{\circ} \mathrm{N}$ in the summer. Mar. Biol. $79,257-267$.

Båmstedt, U. 1986: Chemical composition and energy content. Pp. 1-58 in Corner E. D. S. \& O'Hara S. C. M. (cds.): The biological chemistry of marine copepods. Oxford University Press, New York

Båmstedt, U. 1988: Ecological significance of individual variability in copepod bioenergetics. Hydrobiologia 167/168,4359.

Båmstedt, U. \& Ervik, A. 1984: Local variation in size and activity among Calanus finmarchicus and Metridia longa (Copepoda, Calanoida) overwintering on the west coast of Norway. J. Plankton Res. 6, 843-857.

Båmstedt, U. \& Tande, K. S. 1985: Respiration and excretion rates of Calanus glacialis in arctic waters of the Barents Sea. Mar. Biol. 87, 259-266. 
Båmstedt, U. \& Tande. K. S. 1988: Physiological responses of Calanus finmarchicus and Metridia longa (Copepoda: Calanoida) during the winter-spring transition. Mar. Biol. 49. 31-38.

Båmstedt, U., Tande, K. S. \& Nicolajsen, H. 1985: Ecological investigations on the zooplankton community of Balsfjorden. northern Norway: physiological adaptations in Metridia longa (Copepoda) to the overwintering period. Pp. 313-327 in Gray. J. S. \& Christiansen. M. E. (eds.): Marine biology of polar regions and effects of stress on marine organisms. $J$. Wiley and Sons.

Bätje. M. \& Michaelis, H. 1986: Phaeocystis pouchetii blooms in the east Frisian coastal waters (German Bight, North Sea). Mar. Biol. 93, 21-27.

Berggren, U., Hansen, B. Kiørboe, T. 1988. Food-size spectra. ingestion and growth of the copepod Acartia tonsa: implications for the determination of copepod production. Mar. Biol. 99, 341-352.

Boyd, C. M., Smith. S. L. \& Cowles, T. J. 1980: Grazing patterns of copepods in the upwelling system of Peru. Limnol. Oceanogr. 24. 583-596.

Claustre. H., Poulet, S, A.. Williams, R., Marty. J.-C., Coombs, S., Ben, Mlih. F., Hapette, A. M. \& MartinJezequel, M. 1990: A biochemical investigation of a Phaeocystis sp. bloom in the Irish Sea. J. Mar. Biol. Ass. UK 70. 197-207.

Conover, R, J. \& Corner, E. D. S. 1968: Respiration and nitrogen excretion by some marine zooplankton in relation to their life cycles. J. Mar. Biol. Ass. UK 48. 49-75.

Conover, R. J. \& Francis, V. 1973: The use of radioactive isotopes to measure the transfer of materials in aquatic food chains. Mar. Biol. 18, 272-283.

Dagg. M. J. \& Grill, D. W. 1980: Natural feeding rates of Centropages typicus females in the New York Bight. Limnol. Oceanogr. 25. 597-609.

Dagg. M. J., Vidal. J., Whitledge, T. E., Iverson, R. L. \& Goering, J. J. 1982: The feeding, respiration and excretion of zooplankton the Berings Sea during a spring bloom. DeepSea Res. 29, 45-63.

Dagg, M. J. \& Wyman, K. D. 1983: Natural ingestion rates of the copepods Neocalanus plumchrus and $N$. cristatus calculated from gut contents. Mar. Ecol. Prog. Ser. 13, 37-46.

Eilertsen, H. Chr., Tande. K. S. \& Hegseth, E. N. 1989a: Potential of herbivorous copepods for regulating the spring phytoplankton bloom in the Barents Sea. Rapp. P. -v. Réun. Cons. Int. Explor. Mer 188, 154-163.

Eilentsen. H. Chr., Tande, K. S. \& Taasen, J. P. 1989b: Vertical distribution of primary production and grazing by Calanus glacialis Jaschnov and C. hyperboreus Krøyer in Arctic waters (Barents Sea). Polar Biol. 9. 253-260

Estep. K. W. Nejstgaard. J. Chr., Skjoldal, H. R. \& Rey, F. 1990: Predation by copepods upon natural populations of Phaeacystis pouchetii as a function of the physiological state of the prey. Mar. Ecol. Prog. Ser. 67, 235-249.

Frost, B. W. 1972: Effect of size and concentration of food particles on the feeding behaviour of the marine planktonic copepod Calanus pacificus. Limnol. Oceanogr. 17, 805-815.

Hansen. B.. Berggreen, U. C., Tande, K. S. \& Eilertsen. H. Chr. 1990a: Post-bloom grazing by Calanus glacialis, $C$. finmarchicus and $C$. hyperboreus in the region of the polar front. Barents Sea. Mar. Biol. 104, 5-14.

Hansen. B., Tande. K. S. \& Berggreen. U. C. 1990b: On the trophic fate of Phaeocystis pouchetii (Hariot), III. Functional responses in grazing demonstrated on juvenile stages of $\mathrm{Cal}$. anus finmarchicus (Copepoda) fed diatoms and Phaeocystis J. Plankion Res. 12, 1173-1187.

Head. E. J. H., Bedo, A. \& Harris, L. R. 1988: Grazing. defecation and excretion rates of copepods from inter-island channels of the Canadian Arctic archipelago. Mar. Biol. 99 , 333-340.

Head. E. J. H., Harris, L. R. \& Abou Debs, C. 1985: Effect of daylength and food concentration on in situ diurnal feeding rhythms in Arctic copepods. Mar. Ecol. Prog. Ser, 24. 281288.

Hirche. H.-J. 1990: Egg production of Calanus finmarchicus at low temperature. Mar. Biol. 106. 53-58.

Huntley, M. 1981: Nonselective, nonsaturated feeding by three calanid copepod species in the Labrador Sea. Limnol. Oceanogr. 26, 831-842.

Huntley, M. 1988: Feeding biology of Calanus: a new perspective. Hydrobiologia 167/168, 83-99.

Huntley, M., Tande, K. \& Eilertsen, H. Chr. 1987: On the trophic fate of Phaeocystis pouchetii (Hariot). Il. Grazing rates of Calanus hyperboreus (Krøyer) on diatoms and different size categories of Phaeocystis pouchetii. J. Exp. Mar. Biol. Ecol. 110, 197-212.

Jonsson, P. R. 1986. Particle size selection, feeding rates and growth dynamics of marine planktonic oligotrichous ciliates (Ciliophora: Oligotrichina). Mar. Ecol. Prog. Ser. 33, 265277.

Jonsson. P. \& Tiselius, P. 1990: Feeding behaviour, prey detection and capture efficiency of the copepod Acartia tonsa feeding on planktonic ciliates. Mar. Ecol. Prog. Ser. 60, 35 44

Kayser. H. 1970: Experimental-ecological investigation on Phaeocystis pouchetii (Haptophyceae): Cultivation and waste water test. Helgolander Wiss. Meeresunters. 20, 195-212.

Kiørboe, T., Møhlenberg, F. \& Nicolajsen, H. 1982: Ingestion rate and gut clearance in the planktonic copepod Centropages hamatus (Lilljeborg) in relation to food concentration and temperature. Ophelia 21, 181-194.

Kirk. J. T. O. 1983: Light and photosynthesis in aquatic ecosystems. Cambridge University Press, Melbourne.

Mackas, D. \& Bohrer, R. 1976: Fluorescence analysis of zooplankton gut contents and an investigation of diel feeding patterns. J. Exp. Mar. Biol. Ecol. 25, 77-85.

Nielsen, T. G., Kiørboe, T. \& Bjørnsen, P. K. 1990: Effects of a Chrysochromulina polylepis subsurface bloom on the planktonic community. Mar. Ecol. Prog. Ser. 62, 21-35.

Parsons, T. R., Takahasi, M. \& Hargrave, B. 1977: Biological oceanographical processes. Pergamon Press, Oxford. $332 \mathrm{pp}$.

Peterson. W. T. 1988: Rates of egg production by the copepod Calanus marshallae in the laboratory and in the sea off Oregon. USA. Mar. Ecol. Prog. Ser. 47, 229-237.

Sakshaug. E. \& Slagstad. D. 1991: Light and productivity in polar marine ecosystems: a physiological view. Pp. 69-85 in Sakshaug. E., Hopkins, C. C. E. \& Øritsland, N. A. (eds.): Proceedings of the Pro Mare Symposium on Polar Marine Ecology. Trondheim, 12-16 May 1990. Polar Research 10(1).

Schnack, S. B., Smetacec, V., von Bodungen, B. \& Stegmann, P. 1985: Utilization of phytoplankton by copepods in Antarctic waters during spring. Pp. 65-81 in Gray, J. S. \& Christiansen, M. E. (eds.): Marine Biology of polar regions and effects of stress on marine organisms. J. Wiley and Sons.

Skreslet, S. 1988: Buoyancy in Phaeocystis pouchetii (Hariot) Lagerheim. J. Exp. Mar. Biol. Ecol. 119, 157-166.

Slagstad. D. 1981: Modeling and simulation of physiology and 
population dynamics of copepods. Modeling, Identification and Control 2, 119-162.

Slagstad, D. \& Tande, K. S. 1990: Growth and production dynamics of Calanus glacialis in an arctic pelagic food web. Mar. Ecol. Prog. Ser. 63, 189-199.

Tande. K. S. \& Båmstedt, U. 1985: Grazing rates of the copepods Calanus glacialis and C. finmarchicus in Arctic waters of the Barents Sea. Mar. Biol. 87, 251-258.

Tande, K. S. \& Bamstedt, U. 1987: On the trophic fate of Phaeocystis pouchetii. I. Copepod feeding rates on solitary cells and colonies of $P$. pouchetii. Sarsia 72, 313-320.

Valiela, I. 1984. Marine ecological processes. Springer Verlag, New York. 546 pp.
Verity, P. \& Smayda, T. J. 1989: Nutritional value of Phaeocystis pouchetii (Prymnesiophyceae) and other phytoplankton for Acartia spp. (Copepoda): ingestion, egg production, and growth of nauplii. Mar. Biol. 100, 161-171.

Verity, P. G., Smayda, T. J., Sakshaug, E. 1991. Photosynthesis, excretion, and growth rates of Phaeocystis colonies and solitary cells. Pp. 117-128 in Sakshaug. E.. Hopkins, C. C. E. \& Øritsland, N. A. (eds.): Proceedings of the Pro Mare Symposium on Polar Marine Ecology, Trondheim, 12-16 May 1990. Polar Research IO(I).

Webb. W. L., Newton, M., Starr, D. 1974. Carbon dioxide exchange of Alnus rubra: a mathematical model. Oecologia 17, 281-291. 
